\title{
城都行
}

LOOKING for CHENGDU 
A volume in the series

Anthropology of Contemporary Issues

EdITED by Roger SANJEK 


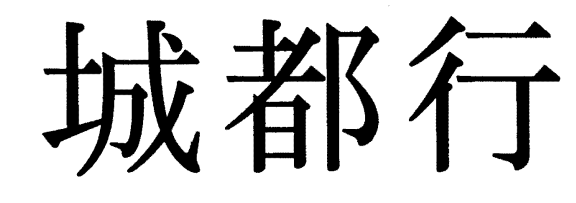

\section{Looking for Chengdu}

\section{A WOMAN'S ADVENTURES IN CHINA}

\section{HILL GATES}

CORNELL UNIVERSITY PRESS

ITHACA AND LONDON 


\section{Copyright $@ 1999$ by Cornell University}

All rights reserved. Except for brief quotations in a review, this book, or parts thereof, must not be reproduced in any form without permission in writing from the publisher. For information, address Cornell University Press, Sage House, 512 East State Street, Ithaca, New York 14850.

First published 1999 by Cornell University Press First printing, Cornell Paperbacks, 1999

Printed in the United States of America

Gates, Hill.

$$
\text { Library of Congress Cataloging-in-Publication Data }
$$

Looking for Chengdu : a woman's adventures in China / Hill Gates.

p. $\mathrm{cm}$. - (The anthropology of contemporary issues)

ISBN o-8014-3646-X. — ISBN o-8014-8632-7 (pbk.)

1. Gates, Hill-Journeys-China. 2. China-Description and travel. I. Title. II. Title: Woman's adventures in China.

III. Series: Anthropology of contemporary issues.

DS712.G37 1999

915.104' 58 - dc21

$99-28430$

Cornell University Press strives to use environmentally responsible suppliers and materials to the fullest extent possible in the publishing of its books. Such materials include vegetable-based, low-VOC inks, and acid-free papers that are recycled, totally chlorine-free, or partly composed of nonwood fibers. Books that bear the logo of the FSC (Forest Stewardship Council) use paper taken from forests that have been inspected and certified as meeting the highest standards for environmental and social responsibility. For further information, visit our website at www.cornellpress.cornell.edu.

Cloth printing $10 \begin{array}{llllllllll}10 & 9 & 8 & 7 & 6 & 5 & 4 & 3 & 2 & 1\end{array}$

$\begin{array}{lllllllllll}\text { Paperback printing } & 10 & 9 & 8 & 7 & 6 & 5 & 4 & 3 & 2 & 1\end{array}$ 